\title{
From days to decades: numerical modelling of freshwater lens response to climate change stressors on small low-lying islands
}

\author{
S. Holding and D. M. Allen \\ Department of Earth Sciences, Simon Fraser University, 8888 University Drive, Burnaby, British Columbia, V5A 1S6, Canada \\ Correspondence to: S. Holding (sholding@ sfu.ca)
}

Received: 18 September 2014 - Published in Hydrol. Earth Syst. Sci. Discuss.: 16 October 2014

Revised: 12 January 2015 - Accepted: 13 January 2015 - Published: 16 February 2015

\begin{abstract}
Freshwater lenses on small islands are vulnerable to many climate change-related stressors, which can act over relatively long time periods, on the order of decades (e.g., sea level rise, changes in recharge), or short time periods, such as days (storm surge overwash). This study evaluates the response of the freshwater lens on a small lowlying island to various stressors. To account for the varying temporal and spatial scales of the stressors, two different density-dependent flow and solute transport codes are used: SEAWAT (saturated) and HydroGeoSphere (unsaturated/saturated). The study site is Andros Island in the Bahamas, which is characteristic of other low-lying carbonate islands in the Caribbean and Pacific regions. In addition to projected sea level rise and reduced recharge under future climate change, Andros Island experienced a storm surge overwash event during Hurricane Francis in 2004, which contaminated the main wellfield. Simulations of reduced recharge result in a greater loss of freshwater lens volume (up to $19 \%$ ), while sea level rise contributes a lower volume loss (up to $5 \%$ ) due to the flux-controlled conceptualization of Andros Island, which limits the impact of sea level rise. Reduced recharge and sea level rise were simulated as incremental instantaneous shifts. The lens responds relatively quickly to these stressors, within 0.5 to 3 years, with response time increasing as the magnitude of the stressor increases. Simulations of the storm surge overwash indicate that the freshwater lens recovers over time; however, prompt remedial action can restore the lens to potable concentrations up to 1 month sooner.
\end{abstract}

\section{Introduction}

Small islands are particularly vulnerable to stressors associated with climate change. The freshwater lens is generally sensitive to hydrological disturbances, as a consequence of the low hydraulic gradient and limited thickness of the lens (Vacher, 1988; Falkland, 1991; Robins and Lawrence, 2000; White and Falkland, 2010). As groundwater recharge is the primary source of freshwater to a freshwater lens, an adequate amount of recharge is critical for maintaining the lens morphology (Falkland, 1991). Changes in groundwater recharge due to climate change are likely to result from increases in temperature and changes in the spatial distribution, frequency and magnitude of precipitation (Green et al., 2011). Conditions of reduced recharge disturb the balance of freshwater outflow necessary to maintain the extent of the freshwater lens, and may lead to loss of freshwater volume due to saltwater intrusion (Oude Essink, 2001; Ranjan et al., 2009).

Sea level rise may result in inundation and a landward shift of the saltwater interface, particularly on low-lying islands (Bear et al., 1999). This would result in a loss of freshwater lens volume, either by a reduction in areal extent and/or a thinning of the lens (Oude Essink, 2001). Projected changes in the frequency of hurricanes and tropical storms are uncertain (IPCC - Intergovernmental Panel on Climate Change, 2014); however, there is evidence to suggest that storms may become more intense, increasing the likelihood of storm surge occurrence (Biasutti et al., 2012). Storm surge overwash can lead to salt contamination of the freshwater lens and a temporary loss of freshwater (Anderson, 2002; Illangasekare et al., 2006; Terry and Falkland, 2010). Due to topography, low-lying islands are more susceptible to saltwater inundation from sea level rise and storm surge overwash. 
Previous modelling studies have investigated aspects of climate change impacts on the freshwater lenses of islands or coastal aquifers. Simulations of decreased recharge resulted in more saltwater intrusion and impact to water supply infrastructure than simulations of sea level rise alone (Rasmussen et al., 2013). However, for regions with future projected increases in recharge, the impact of sea level rise and other stresses (i.e., increases in pumping) may be counteracted by increased recharge (Sulzbacher et al., 2012). Analytical and numerical models of sea level rise indicate that the degree of saltwater intrusion (or loss of freshwater lens volume) resulting from sea level rise depends on many factors. Whether the hydrogeological system is recharge-limited or topographylimited (Michael et al., 2013) influences whether or not the water table rise that accompanies sea level rise can be accommodated by the system. Werner and Simmons (2009) showed that less saltwater intrusion is expected when the system is recharge-limited (flux-controlled). Unsurprisingly, the degree of land surface inundation was found to control the amount of saltwater intrusion (Ataie-Ashtiani et al., 2013), and the impact of sea level rise on saltwater intrusion is enhanced by groundwater extraction from coastal wellfields (Bobba, 2002; Langevin and Zygnerski, 2013).

Models of storm surge overwash events have been developed to evaluate their impact on the freshwater lens. Most of these models used codes that neglect the surface domain. However, Yang et al. (2013) used a fully coupled subsurface and surface approach that simulated tidal activity, coastal flow dynamics, and a hypothetical storm surge on a coastal aquifer. All models indicate initial salt contamination of the freshwater lens, which recovers to fresh concentrations over time due to freshwater recharging at surface and densitydriven downward migration of salt water (Terry and Falkland, 2010). The occurrence of multiple storm surges (Anderson, 2002) and accumulations of salt water at the surface in low depressions (Chui and Terry, 2012) may increase the time for recovery of the lens. Where the vadose zone becomes thinner under conditions of sea level rise (because the freshwater lens has risen in the subsurface), the impact of storm surge alongside sea level rise may result in less salt contamination of the freshwater lens (Chui and Terry, 2013). However, the salt contamination that does occur under sea level rise conditions remains close to the surface of the lens (Terry and Chui, 2012). Wider islands generally result in less freshwater lens contamination than narrow islands, as a result of their thicker lens morphology (Chui and Terry, 2013).

Although many aspects of climate change impacts on freshwater lenses have been modelled previously, few studies have investigated both the spatial and temporal response of the freshwater lens to the stressors. Climate change related stressors operate on various spatial and temporal scales: island-wide impacts due to sea level rise and changes in recharge occur over long time periods, on the order of decades, whereas local-scale impacts due to storm surge overwash occur over short time periods, on the order of days.
This study evaluates the spatial and temporal response of an island freshwater lens to various climate change stressors using a numerical modelling approach. To account for the varying temporal and spatial scales of the stressors, two different density-dependent flow and transport modelling codes are used. SEAWAT (Langevin et al., 2007) models were developed on an island scale to simulate long-acting stressors, including sea level rise and change in recharge. HydroGeoSphere (Therrien et al., 2010) models were developed on a local scale to simulate storm surge, which is a short-acting stressor. The study aims to identify critical factors and stressors that may affect freshwater resources of small, low-lying islands, using Andros Island in the Bahamas as a representative island. The results of the study are intended to be applicable to other islands with similar hydrogeological settings.

\section{Site description}

The study site is Andros Island in the Bahamas. Andros Island has undergone limited development and groundwater exploitation; therefore, the hydrogeological data collected in the 1970s (Little et al., 1973) are considered generally representative of current conditions and can be used for baseline model calibration. Andros Island is representative of other low-lying carbonate islands with thin freshwater lenses commonly found throughout the Caribbean and Pacific regions (Falkland, 1991; Vacher and Quinn, 1997).

Andros Island is the largest island in the Bahamas, and is located $200 \mathrm{~km}$ southeast of Florida (Fig. 1). It is $14000 \mathrm{~km}^{2}$ in area and is comprised of several smaller islands and cays. The highest elevation on the island is $20 \mathrm{~m}$ a.s.l. (metres above sea level) along a ridge that parallels the eastern coast, whereas lower elevations $(<1 \mathrm{~m}$ a.s.l.) are common towards the west. The western coastline is largely composed of wetlands and saltwater marshes, and, therefore, most settlements are along the eastern coast of the island (Fig. 1). The remainder of the island is largely covered in pine forest. There are no permanent surface water bodies on the island.

Andros Island is located on the Great Bahama carbonate bank (Fig. 1). The geology of the island is a predominantly Pleistocene Lucayan limestone formation, which is around $40 \mathrm{~m}$ thick (Beach and Ginsburg, 1980). Discontinuity surfaces (unconformities) within the limestone are present as layers of paleosols recurring in the upper stratigraphy (Beach and Ginsburg, 1980). These layers represent episodes of subaerial exposure and are largely concentrated within the top $20 \mathrm{~m}$ (Beach and Ginsburg, 1980; Boardman and Carney, 1997). Underlying the Lucayan is a cavernous, highly karstic, and relatively more permeable unit termed the pre-Lucayan, which is present from $43 \mathrm{~m}$ b.g.s. (metres below ground surface) to at least $75 \mathrm{~m}$ b.g.s. (Boardman and Carney, 1997). The geology below this depth has not been observed as most studies focus on the shallow, freshwater-bearing units; how- 


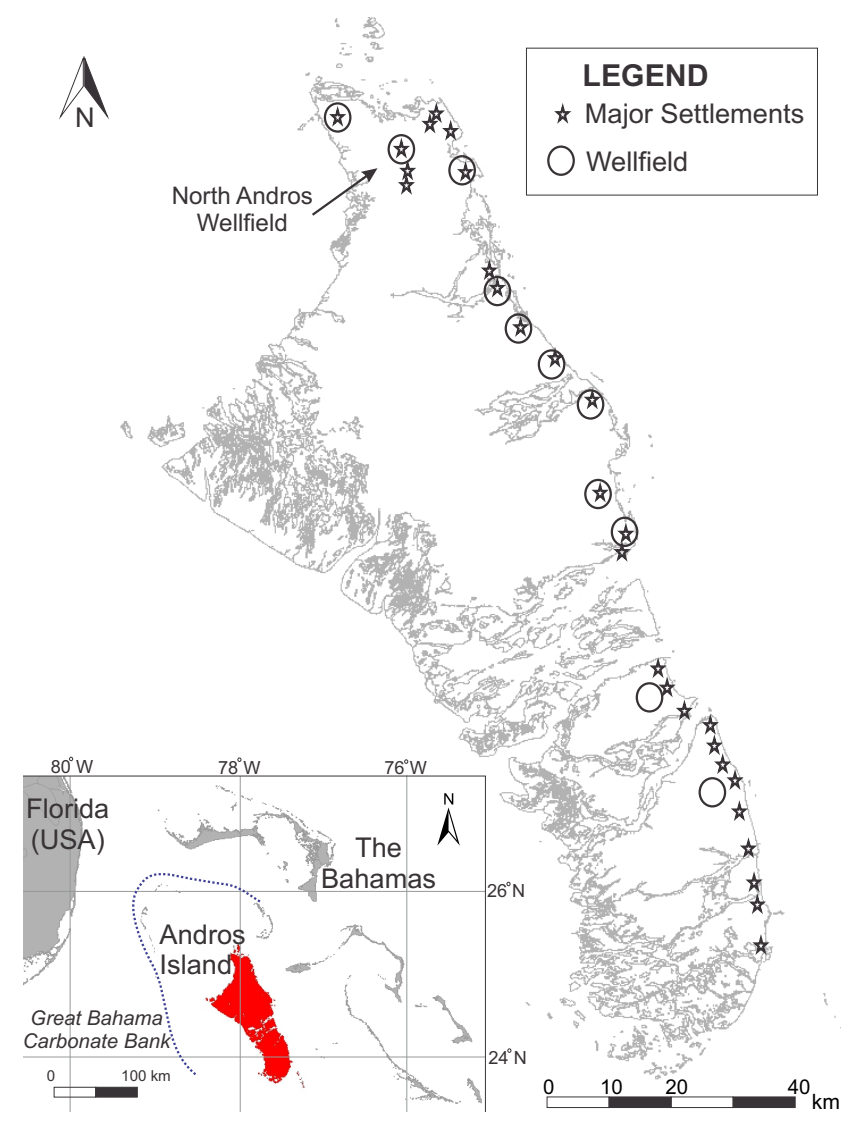

Figure 1. Andros Island, indicating the location of settlements and wellfields.

ever, deposits of carbonates on the Great Bahama bank are estimated to be up to $7 \mathrm{~km}$ thick (Cant and Weech, 1986).

Due to its large size, the freshwater lens on Andros Island represents the principal source of natural freshwater for the Bahamas. Most local residents rely on the municipal potable water supply $\left(<0.4 \mathrm{~g} \mathrm{~L}^{-1}\right.$ salt concentration), which extracts groundwater from the lens via 11 wellfields distributed across the island (Fig. 1). The local drinking water guidelines define potable water as having salt concentrations of less than $0.4 \mathrm{~g} \mathrm{~L}^{-1}$. The largest of these wellfields is the North Andros Wellfield. As is common with many freshwater lenses, there is potential for upconing of the underlying saltwater and degradation of the lens if wells are deep and the lens thin (Werner et al., 2009; White and Falkland, 2010). Therefore, the wellfields on Andros employ horizontal trench-based groundwater extraction or a series of interconnected shallow boreholes pumped at low rates. Typical depth of the wellfields is between 1 and $5 \mathrm{mb}$ b.g.s. Water flows within the trench-based wellfields under a very low gradient, towards a central low sump where water is pumped to storage reservoirs.

The hydrogeology of Andros Island is based on previous studies, most of which were conducted around the wellfields and other developed areas. The principal aquifer is the un- confined Lucayan limestone, as the older (deeper) geological units are too permeable and thus are not able to prevent freshwater from mixing with the surrounding saltwater (Cant and Weech, 1986; Schneider and Kruse, 2003). Soil zones are sparse, and minimal runoff occurs during precipitation events (Little et al., 1973; Tarbox, 1987). The freshwater lens is recharged solely through infiltrating precipitation, which generally occurs during the wet season from May to October (Bukowski et al., 1999). Average annual precipitation in the south is $39 \%$ less than average annual precipitation in the north of Andros Island (Cant and Weech, 1986; Bahamas Department of Meteorology, Climate Averages 19792000). Based on resistivity surveys conducted in the north of the island, the thickness of the freshwater lens ranges from 3 to $20 \mathrm{~m}$ (Wolfe et al., 2001); however, previous studies cite the maximum thickness as $34 \mathrm{~m}$ (Cant and Weech, 1986) and borehole salinity profiles indicate that the maximum thickness of the lens is up to $39 \mathrm{~m}$ (Little et al., 1973). The lens is generally shallower in the southern regions of Andros Island compared to the northern regions, with a measured thickness of at least $15 \mathrm{~m}$ b.g.s. (municipal water supply managers, Bahamas Water and Sewerage Corporation, personal communication, 2013). The elevation of the lens inland is approximately $2 \mathrm{~m}$ a.s.l. (Ritzi et al., 2001) with typical depth to water of 1-2 mb.g.s., although it is deeper (up to $5 \mathrm{~m}$ b.g.s.) under the high topography ridge along the eastern coast (Little et al., 1973; Boardman and Carney, 1997). The hydraulic conductivity of the principal aquifer (Lucayan limestone) is estimated to range from 86 to $8640 \mathrm{mday}^{-1}$ based on short-duration, single-well specific capacity pumping tests conducted in the 1970s (Whitaker and Smart, 1997). The hydraulic gradient (ranging from 0.0005 to 0.001 ) was determined from historic field observations and estimates of the freshwater lens morphology (Little et al., 1973). Porosity ranges from 10 to $20 \%$ (Bukowski et al., 1999). Sparse hydrogeological field data are available for the majority of the island; therefore, in the past, the morphology of the freshwater lens was largely inferred based on vegetation patterns, geological setting and anecdotal observations. Because Andros Island is composed of several small islands and cays, the freshwater lens is also composed of multiple lenses present on the different land masses. Lenses are anticipated to be present across most of the island, except in areas that are heavily intersected by saltwater marshes and wetlands.

In September 2004, Hurricane Frances caused a storm surge on the western coast of Andros Island, which resulted in extensive salinization of the North Andros Wellfield (Fig. 2). The hurricane ranged from a Category 4 to Category 2 on the Saffir Simpson Hurricane Scale while it travelled across the Bahamas from the southeast to northwest (Franklin et al., 2006). The surge occurred 3-4 September 2004, while Hurricane Frances passed near Andros Island. The exact time of occurrence of the storm surge and the actual extent of the overwash are unknown because the western coast of Andros Island is largely unpopulated. However, 


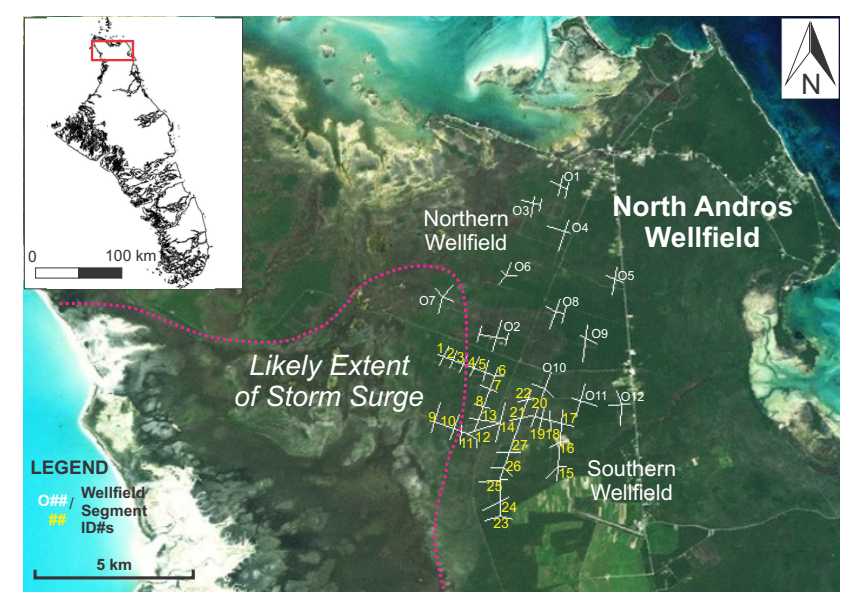

Figure 2. Layout of the North Andros Wellfield indicating the likely extent of the 2004 Hurricane Frances storm surge overwash.

after the hurricane had passed, evidence of the overwash was observed, such as flooded ground and the presence of marine fish at inland locations (Bowleg and Allen, 2011). The likely extent of the overwash is thus based on observations of damage following the surge (e.g., water marks on trees, presence of seaweed and marine organisms, etc.), and is shown in Fig. 2.

Salinity concentration data from the southern wellfield (Fig. 2) were provided from the water managers for the dates May 2004 (pre-storm), 7 September (immediately poststorm surge), 15 September (following remedial action) and July/August 2005 (approximately 1 year post-storm surge). These data are presented in Fig. 3, which illustrates the abrupt increase in salinity within the trenches following the storm surge and the eventual recovery to pre-storm concentrations. As a form of remedial action, the contaminated trenches were pumped to remove the ponded seawater beginning on 8 September (approximately 4 days following the storm surge). Salinity in the affected trenches improved, reducing by up to $88 \%$ on 15 September, relative to the maximum recorded concentrations in each trench. However, remedial pumping of the trenches was not completed because freshwater was required to support post-hurricane relief efforts on other islands. Therefore, some of the contaminated trenches were closed off from the wellfield system to allow for extraction of freshwater from the unaffected parts of the freshwater lens and were not drained. Several of these contaminated trenches remained closed for 2 years due to poor water quality. Trenches that were drained are distinguished from those that were not in Fig. 3. The wellfield eventually recovered to normal salinity concentrations between 1 and 2 years post-storm, with all trenches recovered by 2009 .

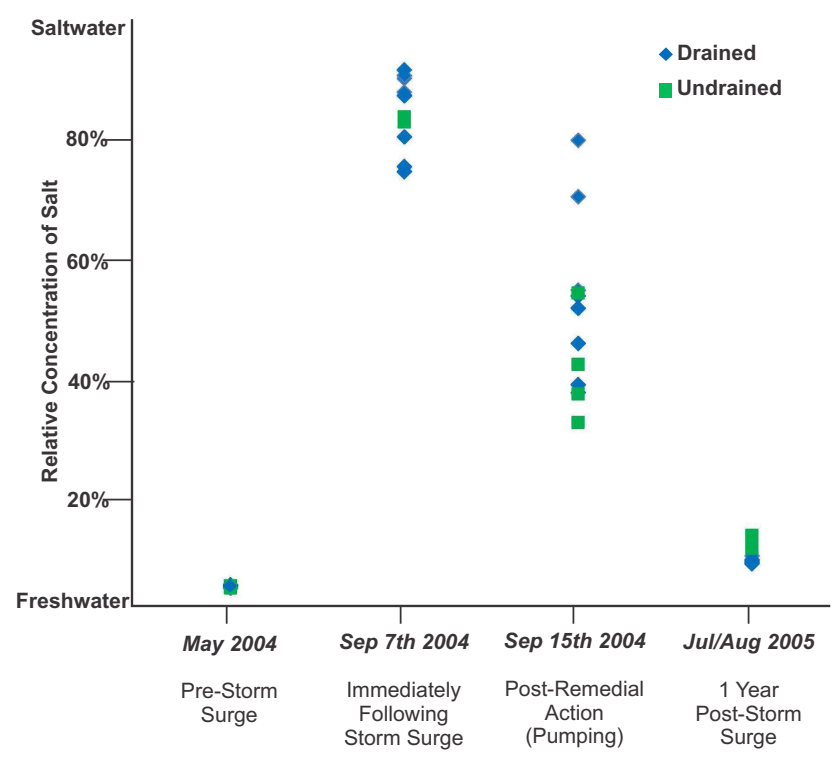

Figure 3. Salinity monitoring data before and after the 2004 Hurricane Frances storm surge. Data are shown for the southern trench segments of the North Andros Wellfield only (shown in yellow on Fig. 2).

\section{Methodology}

\subsection{SEAWAT model: long-acting stressors}

\subsubsection{Baseline model setup}

A three-dimensional numerical density-dependent groundwater flow and solute transport model was developed using SEAWAT. The island was simulated using two separate models, a northern and southern model, to allow for refined grid resolution and a reasonable run time for each simulation. Each model was run for 100 years, during which time the freshwater lenses developed; both models reached steady state (i.e., no further change in lens morphology) within 20 25 years. Specified head boundaries were defined along the perimeter of the domain to simulate sea level, with density specified at $1.025 \mathrm{~kg} \mathrm{~L}^{-1}$, representative of typical seawater composition. Specified concentration boundaries were assigned to the same grid cells as the specified head boundaries with concentrations of $35 \mathrm{~g} \mathrm{~L}^{-1}$ salt. The initial concentration of the entire model domain was specified at $35 \mathrm{~g} \mathrm{~L}^{-1}$ salt. The ground surface for the model was based on a digital elevation model for Andros Island ( $90 \mathrm{~m}$ resolution). The model grid was uniform in plan view, with each grid cell $500 \mathrm{~m}$ by $500 \mathrm{~m}$. In the vertical dimension, the model included 44 layers, with individual layer thicknesses of $1 \mathrm{~m}$ in the upper $20 \mathrm{~m}$ of the model domains, which transitioned to $2.5,5$ and then $10 \mathrm{~m}$ thickness from a depth of $60 \mathrm{~m}$ to the base of the domain ( $200 \mathrm{~m}$ b.g.s.).

Hydraulic conductivity of the principal aquifer was based on field data (Little et al., 1973) and a sensitivity analysis was 
Table 1. SEAWAT model parameters.

\begin{tabular}{|c|c|}
\hline Parameter & Value \\
\hline Model domain & $200 \mathrm{~m}$ deep; lateral extent based on island area \\
\hline Lucayan/pre-Lucayan interface & $40 \mathrm{~m}$ b.g.s. \\
\hline Paleosol depths & 9-10 and $14-15 \mathrm{~m}$ b.g.s. \\
\hline Hydraulic conductivity & $\begin{array}{l}\text { Lucayan: } 864 \mathrm{~m} \text { day }^{-1} \text { - paleosols: } 8640 \mathrm{~m} \mathrm{day}^{-1} \\
\text { - pre-Lucayan: } 86400 \mathrm{~m} \mathrm{day}^{-1}\end{array}$ \\
\hline Specific storage/specific yield & $1 \times 10^{-5} \mathrm{~m}^{-1} / 0.15$ \\
\hline Effective porosity & 0.15 \\
\hline Dispersivity & $\begin{array}{l}\text { Longitudinal } 1.0 \mathrm{~m} \text {; transverse } \\
\text { (vertical \& horizontal) } 0.1 \mathrm{~m}\end{array}$ \\
\hline Specified head boundary & $\begin{array}{l}0 \text { m a.s.l. along model domain periphery; } \\
\text { specified density } 1.025 \mathrm{~kg} \mathrm{~L}^{-1}\end{array}$ \\
\hline Concentration at specified head boundary & $35 \mathrm{~g} \mathrm{~L}^{-1}$ along model domain periphery \\
\hline Initial concentration & $35 \mathrm{~g} \mathrm{~L}^{-1}$ throughout model domain \\
\hline Recharge & $\begin{array}{l}877 \mathrm{~mm} \mathrm{yr}^{-1} \text { (north) and } 426 \mathrm{~mm} \mathrm{yr}^{-1} \\
\text { (south); concentration } 0 \mathrm{~g} \mathrm{~L}^{-1}\end{array}$ \\
\hline Time steps & Initial: 14 min; maximum: 1 day \\
\hline
\end{tabular}

conducted to identify the optimal configuration and hydraulic properties of the layers to simulate the observed freshwater lens thickness on Andros Island. Previous studies had characterized the paleosols as low hydraulic conductivity layers (Ritzi et al., 2001); however, anecdotal evidence indicates that the layers are very weathered and may be highly conductive. In this study, the paleosols are represented by relatively high hydraulic conductivity layers (interbeds) within lower permeability limestone. This layer configuration with the assigned layer hydraulic properties is supported by model calibration. Assigning a low conductivity to the paleosols resulted in the lens being perched, which is not observed in the field. Whereas, representing the paleosols as high conductivity layers within lower conductivity limestone resulted in thin lenses being developed, similar to field observations. This approach is consistent with other studies based in the Bahamas, which have suggested that layers of high hydraulic conductivity in the subsurface are responsible for thin freshwater lenses (Wallis et al., 1991). The optimal configuration of aquifer layers and hydraulic conductivities are provided in Table 1.

Recharge was applied to the top layer of the model with concentration of $0 \mathrm{~g} \mathrm{~L}^{-1}$ salt to simulate the average annual recharge to the aquifer. Recharge is the only input of freshwater to the hydrogeological system and, therefore, is the main mechanism by which the simulated freshwater lens develops in the model. The annual recharge amount for Andros Island was estimated using the United States Environmen- tal Protection Agency's software HELP (Hydrologic Evaluation of Landfill Performance) (Schroeder et al., 1994). HELP utilizes a storage routing technique based on hydrological water balance principles. It accounts for soil moisture storage, runoff, interception, and evapotranspiration. HELP has been used to estimate recharge for a variety of climatic and physiographic settings (Scibek and Allen, 2006; Jyrkama and Sykes, 2007; Toews and Allen, 2009; Allen et al., 2010).

Within HELP, a representative vertical percolation profile was defined for the unsaturated zone. The depth of the profile was $2 \mathrm{~m}$, based on a sensitivity analysis using the minimum and maximum observed depths to the water table on Andros Island. No soil zone was specified due to the generally thin/absent soils on Andros Island (Little et al., 1973). The lithology was homogeneous (representing limestone), with a saturated hydraulic conductivity $\left(864 \mathrm{~m} \mathrm{day}^{-1}\right)$ based on the mean value from field studies (Little et al., 1973) and the calibrated value from the baseline SEAWAT model. Vegetation cover was assigned to the highest class in the software (a leaf area index of 5) based on the large proportion of pine forests. The surface was assigned zero slope given that minimal runoff is observed. The wilting point was assigned 0.05 and field capacity 0.1 in the absence of measured values.

Two 100 year climate data series were generated using the embedded stochastic weather generator; one for North Andros and one for South Andros because the historical climate differs between the two regions. The average annual precipitation on North Andros is $1442 \mathrm{~mm} \mathrm{yr}^{-1}$, while on South An- 
Table 2. Projected climate shifts for the 2090s, and the resulting projected values for monthly mean temperature and monthly mean precipitation for North and South Andros.

\begin{tabular}{|c|c|c|c|c|c|c|c|c|c|c|c|c|}
\hline Parameter & $\mathrm{D}$ & $\mathrm{J}$ & $\mathrm{F}$ & M & A & M & $\mathrm{J}$ & $\mathrm{J}$ & $\mathrm{A}$ & $\mathrm{S}$ & $\mathrm{O}$ & $\mathrm{N}$ \\
\hline Temperature shift $\left({ }^{\circ} \mathrm{C}\right)$ & & +2.8 & & & +3.0 & & & +3.2 & & & +3.2 & \\
\hline $\begin{array}{l}\text { Projected monthly } \\
\text { mean temperature } \\
\left({ }^{\circ} \mathrm{C}\right) \text { North/south }\end{array}$ & 25.2 & 24.3 & 24.6 & 25.3 & 26.8 & 28.5 & 30.4 & 31.3 & 31.3 & 30.9 & 32.7 & 27.7 \\
\hline $\begin{array}{l}\text { Precipitation shift } \\
(\mathrm{mm})\end{array}$ & & -2 & & & -18 & & & -24 & & & +12 & \\
\hline $\begin{array}{l}\text { Projected monthly } \\
\text { mean precipitation } \\
(\mathrm{mm}) \text { North }\end{array}$ & 45 & 48 & 50 & 47 & 66 & 90 & 189 & 138 & 210 & 190 & 176 & 98 \\
\hline $\begin{array}{l}\text { Projected monthly } \\
\text { mean precipitation } \\
(\mathrm{mm}) \text { South }\end{array}$ & 51 & 34 & 37 & 24 & 27 & 89 & 81 & 40 & 57 & 112 & 138 & 103 \\
\hline
\end{tabular}

dros, it is $889 \mathrm{~mm} \mathrm{yr}^{-1}$. Temperature averages were not available for South Andros; therefore, the monthly averages for North Andros were applied to both models. Other climate parameters (e.g., windspeed and relative humidity) were identical for both models. The historical statistical parameters for climate were based on values for the nearest climate station (Miami, Florida, USA) in the weather generator database.

The average annual recharge for the north was estimated at $877 \mathrm{~mm} \mathrm{yr}^{-1}$, with a minimum monthly average of $24 \mathrm{~mm} \mathrm{month}^{-1}$ in December and a maximum monthly average of $163 \mathrm{~mm} \mathrm{month}^{-1}$ in August. The average annual recharge for the south was estimated at $426 \mathrm{~mm} \mathrm{yr}^{-1}$, with a minimum monthly average of $17 \mathrm{~mm} \mathrm{month}^{-1}$ in February and a maximum monthly average of $70 \mathrm{~mm} \mathrm{month}^{-1}$ in October. These values were used as input for the northern and southern SEAWAT models, respectively.

The hydrogeological parameters assigned to the SEAWAT model, based on field data and sensitivity analyses, are summarized in Table 1. Storage parameters were based on common values for the aquifer lithology (Younger, 1993). The wellfields were not simulated in the baseline model in order to represent natural historical conditions. Given their small size, the wellfields are not anticipated to affect the freshwater lens response. If the system were head-controlled, however, on a local scale a rise in water table could result in more loss of freshwater from the top of the lens.

\subsubsection{Climate change simulations}

Future climate for this study was based on published climate change projections for the Bahamas (UNDP - United Nations Development Programme, 2010). The projections were derived from 15 global climate models (GCMs) simulating three emissions scenarios (SRES A2, A1B, and B1). Summaries of projected changes were compiled as seasonal shifts for 3 month groupings (McSweeney et al., 2010). For each grouping, a range in values (minimum, median, and max- imum) for each emissions scenario were provided for the 2030s, 2060s and 2090s. The median seasonal shift in temperature and precipitation projected for the 2090s for the A2 scenario (expected to result in the greatest change) was selected for Andros Island, as summarized in Table 2. Average daily temperature for the 2090 s is projected to increase during all seasons (between 2.8 and $3.2^{\circ} \mathrm{C}$ ). Changes to precipitation are projected to occur primarily during the summer (up to $42 \%$ reduction relative to current conditions). Overall, the projected climate shifts represent conditions with less precipitation and higher temperatures - a drier and hotter climate state.

Changes to groundwater recharge were determined by remodelling recharge in HELP using the projected 2090s climate. The seasonal climate shifts (applied evenly to each month according to season) were applied to the monthly normals for temperature and precipitation in the weather generator, and a new stochastic weather series was generated to represent the projected future climate. This approach is consistent with that used in other studies (e.g., Scibek and Allen, 2006). The adjusted climate data series was then used as input to the vertical percolation profile to determine the annual average groundwater recharge expected under projected climate change. As in the baseline recharge modelling, recharge estimates were produced for North and South Andros, and these values were applied to the SEAWAT models for each region, respectively. The predicted average annual recharge for the north was $777 \mathrm{~mm} \mathrm{yr}^{-1}$, with a minimum monthly average of $18 \mathrm{~mm} \mathrm{month}^{-1}$ in March and a maximum monthly average of $130 \mathrm{~mm} \mathrm{month}^{-1}$ in August. The predicted average annual recharge for the south was $360 \mathrm{~mm} \mathrm{yr}^{-1}$, with a minimum monthly average of $4 \mathrm{~mm} \mathrm{month}^{-1}$ in July and a maximum monthly average of $82 \mathrm{~mm} \mathrm{month}^{-1}$ in November.

Sea level rise was simulated by increasing the elevation of the specified head boundaries in the model domain. Loss of land surface due to inundation associated with sea level rise was not simulated, as the grid resolution of the model is 
larger than the inundation anticipated based on ground surface elevation. Therefore, the boundaries at the edge of the model domain are anticipated to remain at the same model grid cell, only representing a higher specified head value. Although sea level rise has been already observed over the last several decades (White et al., 2005), there is uncertainty as to the rate that it will occur in the future (Rahmstorf, 2007). Geographic variability in the rates of sea level rise is also expected (White et al., 2005). Therefore, a predicted mean sea level increase of $0.6 \mathrm{~m}$ by the 2090s (relative to 1980) was selected as an average estimate based on global and regional projections of sea level rise (IPCC, 2007; Rahmstorf, 2007; Obeysekera, 2013). The hydrogeological system of Andros Island is considered recharge-limited rather than topographylimited, because there is some capacity for the freshwater lens to rise in the unsaturated zone without leading to surface flooding (Werner and Simmons, 2009).

Both the reduction in recharge and sea level rise were simulated in the models as incremental instantaneous shifts. Three models were run: one for recharge reduction alone, one for sea level rise alone, and one including both stressors. The baseline model was run for 50 years to allow the freshwater lens to develop. The recharge and specified head boundary values were then adjusted every 10 years until reaching the projected values for the 2090s. This assumes uniform rates of change throughout the 100 year simulation.

Observation wells were defined in the models to capture a discrete record of simulated concentration for every time step. The observation wells were located within the center and at the edge of the freshwater lens to represent areas that are anticipated to be, respectively, most resilient and most vulnerable to stressors. The northern model consists of one landmass and, therefore, one principal lens, whereas the southern model consists of multiple landmasses. As discussed below, two principal lenses form in the southern model. Therefore, two observation wells were assigned in the northern model and four observation wells were assigned in the southern model, representing central and peripheral wells for each anticipated freshwater lens. The wells are identified as $\mathrm{A}$ and $\mathrm{B}$ to distinguish between the two principal lenses in the southern model. Each well was screened from the ground surface to $5 \mathrm{~m}$ b.g.s., corresponding to the maximum depth of most wells/wellfields on Andros Island.

In order to evaluate changes to the freshwater lens morphology in response to climate change, the SEAWAT model island-scale results were quantitatively evaluated using a geographic information system (GIS). The volume and area of the lens were calculated based on a threshold salt concentration $0.4 \mathrm{~g} \mathrm{~L}^{-1}$ or less (representing local potable water guidelines) and porosity. Although there are inaccuracies inherent in this approach, it provides an estimate of the lens morphology that allows for quantitative comparison of the changes in freshwater lens morphology between different stressors applied in the island-scale model. This threshold concentration is based on the water quality guidelines for salinity in the municipal supply on Andros Island. It also falls within common definitions of freshwater containing less than $1.0 \mathrm{~g} \mathrm{~L}^{-1}$ of total dissolved solids (Freeze and Cherry, 1977; Barlow, 2003). The World Health Organisation (WHO) drinkingwater guidelines do not stipulate a maximum threshold for salt in water, except as it relates to unacceptable taste. The WHO recognizes that water that tastes fresh often has a salt concentration of less than $0.25 \mathrm{~g} \mathrm{~L}^{-1}$; however, in regions where there is naturally more salt in the water, there may be a higher taste threshold (WHO, 2011).

\subsection{HydroGeoSphere model: short-acting stressor}

Modelling the impact of storm surge overwash on a hydrogeological system involves simulating density-dependent flow and solute transport across the surface, the vadose zone and the saturated domain. HydroGeoSphere (HGS) was identified as the most suitable tool to simulate these coupled processes because it is a fully integrated surface and variably saturated subsurface model that is capable of simulating these processes across all domains. By solving the surface and subsurface flow equations simultaneously, HGS provides more realistic representations of the major processes than simpler or independently coupled models (Goderniaux et al., 2009).

One of the mechanisms of aquifer contamination following storm surge is from open wells or trenches that provide direct access to the water table and collect the salt water during inundation (Terry and Falkland, 2010). In addition, salt water trapped within a borehole, or other direct pathway into the aquifer, may lead to prolonged release of salt water into the surrounding aquifer over time (Illangasekare et al., 2006). These features may delay recovery of the aquifer and, therefore, are an important component to include in modelling studies of storm surge impacts (Chui and Terry, 2013). Major consequences to water supply are likely to result when storm surge waves strike trench-based wellfields or open boreholes, as occurred on Andros Island in 2004. Notwithstanding this risk, trench-based wellfields are commonly used on lowlying islands to limit upconing. The models developed for this study aim to characterise aquifer damage and recovery from a storm surge overwash, specifically in the context of a trench-based wellfield and the impact on water supply.

The model domain represents a highly discretized, twodimensional cross-section of one of the trenches in the North Andros Wellfield (Fig. 4). The size of the model domain had to be made as small as possible for computational reasons. Therefore, several different model configurations were tested by varying the model domain width and the hydraulic conductivity distribution (limestone and paleosols) to identify the optimal combination of parameters that best approximates observed conditions. The physically based seawater boundaries are important components in simulating flow within a freshwater lens. In reality, these boundaries are located along the coastline; however, the coastline is far from the North Andros Wellfield. Therefore, local-scale models 


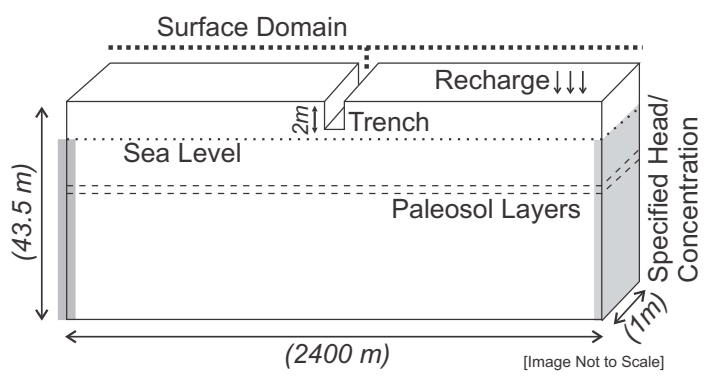

Figure 4. HydroGeoSphere model domain and boundary conditions.

were developed using boundary conditions assigned in such a way as to simulate a realistic flow field surrounding the trench. The local-scale models were calibrated based on critical factors that are expected to affect freshwater lens contamination and recovery. These critical factors include recharge, thickness of the vadose zone, aquifer hydraulic conductivity, geological heterogeneity (e.g., paleosols), water table gradient, and thickness of the freshwater lens. Field data for each of these factors (as presented earlier) comprise the calibration criteria as summarized in Table 3.

With increasing model domain width, the elevation of the water table and gradient both increase, whereas the thickness of the lens decreases. The opposite response was observed when hydraulic conductivity was increased. The model setup that satisfied the calibration criteria with the smallest domain width was selected as the baseline model for this study (Fig. 4).

The model uses block elements that range from 0.35 to $1.0 \mathrm{~m}$. Grid refinement was done in order to optimise simulation of flow and transport across the three hydrologic domains and to allow for the evaluation of small-scale changes in response to overwash. The model domain covers a horizontal extent of $2400 \mathrm{~m}$ and a vertical extent of $43.5 \mathrm{~m}$, with sea level assumed to be $3.5 \mathrm{~m}$ b.g.s. The vertical extent of the domain was determined to represent the Lucayan limestone. The model domain was 1 unit thickness, with a uniform horizontal grid spacing of $1 \mathrm{~m}$. Vertical grid refinement varied from $1 \mathrm{~m}$ thick in the lower $20 \mathrm{~m}$, to $0.5 \mathrm{~m}$ thick in the overlying $20 \mathrm{~m}$, and $0.35 \mathrm{~m}$ thick in the uppermost $3.5 \mathrm{~m}$. Paleosols were simulated in the subsurface as $1 \mathrm{~m}$ thick zones at 9 and $14 \mathrm{~m}$ b.g.s. (corresponding to field observations). The hydraulic conductivity was defined as isotropic at $86.5 \mathrm{~m}^{\text {day }}{ }^{-1}$ for the portion of the domain representing the Lucayan limestone and $865 \mathrm{~m} \mathrm{day}^{-1}$ for the paleosols. The hydraulic conductivities lie within the observed range, although they are lower than that used in the SEAWAT model in order to calibrate the freshwater lens morphology on the local scale surrounding the trench. The underlying high conductivity preLucayan limestone was not included in the model, as it was observed not to have a significant impact on the freshwater lens morphology on the scale of the model.
Table 3. Observed conditions used for calibrating the HydroGeoSphere model.

\begin{tabular}{ll}
\hline Parameter & Value \\
\hline Vadose zone thickness & $1.5-2 \mathrm{~m}$ \\
Water table elevation & $2 \mathrm{~m}$ a.s.1. \\
Gradient & $0.0005-0.001$ \\
Average velocity & $0.3 \mathrm{~m} \mathrm{day}^{-1}$ \\
Thickness of lens & $15-20 \mathrm{~m}$ \\
\hline
\end{tabular}

The trench itself extends $2 \mathrm{mb.g.s.}$, intersecting the top of the water table. Most trench-based wellfields rely on gravity flow; therefore, water tends to move very slowly within the trenches and is observed to be almost stagnant unless the trench is actively being drained. Therefore, lateral flow within the trench was assumed to have a negligible impact on the storm surge impact and recovery of the aquifer. The model provides a snapshot of the impact of trench-based wellfields in terms of salt water capture and transport into the aquifer, which may be scaled up to represent the whole wellfield.

Specified head with associated concentration boundaries were assigned to both sides of the model to represent the surrounding seawater (Fig. 4). Recharge was applied to the surface domain as an annual average quantity based on the HELP recharge modelling, presented earlier. Recharge provides the only input of freshwater that enables the freshwater lens to develop. The boundary conditions and hydrogeological parameters assigned to the HGS model are summarized in Table 4.

The simulation of storm surge overwash required three separate modelling phases: (1) development of the freshwater lens to steady state conditions; (2) short temporal-scale modelling of the rise in salt water height accompanying the overwash; and (3) recovery of the freshwater lens. The heads and concentrations at the end of each phase are used as initial conditions for the subsequent phases; however, the boundary conditions are changed to reflect the different scenarios. The three phases are required to accommodate the different temporal scales (i.e., decades for lens development and minutes for storm surge occurrence) as well as to assign the timevarying boundary conditions. All model simulations used the same initial steady state freshwater lens (Phase 1) and simulation of the storm surge overwash (Phase 2). Different scenarios of remedial action were simulated for Phase 3 and compared to the baseline recovery scenario.

\subsubsection{Phase 1: freshwater lens development}

Phase 1 is a model spin-up period during which the freshwater lens develops. The initial concentration in the baseline model domain was salty $\left(35 \mathrm{~g} \mathrm{~L}^{-1}\right)$, with the only source of freshwater being recharge. The model was run for 50 years to reach steady state. 
Table 4. HydroGeoSphere model parameters.

\begin{tabular}{|c|c|}
\hline Parameter & Value \\
\hline Model domain & $\begin{array}{l}2400 \mathrm{~m} \text { model domain width; } 43.5 \mathrm{~m} \text { domain } \\
\text { depth (representing Lucayan limestone) }\end{array}$ \\
\hline Paleosol depths & $9-10$ and $14-15 \mathrm{~m}$ b.g.s. \\
\hline Trench dimensions & $1 \mathrm{~m}$ wide, $2 \mathrm{~m}$ deep \\
\hline Hydraulic conductivity & $\begin{array}{l}\text { Lucayan limestone: } 86.4 \mathrm{~m} \mathrm{day}^{-1} \text {; } \\
\text { paleosols: } 864 \mathrm{~m} \mathrm{day}^{-1}\end{array}$ \\
\hline Effective porosity & 0.15 \\
\hline Specific storage & $1 \times 10^{-5} \mathrm{~m}^{-1}$ \\
\hline Dispersivity & $\begin{array}{l}\text { Longitudinal } 1.0 \mathrm{~m} \text {; transverse horizontal } 0.1 \mathrm{~m} \text {; } \\
\text { transverse vertical } 0.01 \mathrm{~m}\end{array}$ \\
\hline $\begin{array}{l}\text { Specified head } \\
\text { boundary }\end{array}$ & $\begin{array}{l}0 \mathrm{~m} \text { a.s.l. along model domain periphery; } \\
\text { specified density } 1.025 \mathrm{~kg} \mathrm{~L}^{-1}\end{array}$ \\
\hline $\begin{array}{l}\text { Concentration at specified } \\
\text { head boundary }\end{array}$ & $35 \mathrm{~g} \mathrm{~L}^{-1}$ along model domain periphery \\
\hline Initial concentration & $35 \mathrm{~g} \mathrm{~L}^{-1}$ throughout model domain \\
\hline Recharge & $877 \mathrm{~mm} \mathrm{yr}^{-1}$; concentration $0 \mathrm{~g} \mathrm{~L}^{-1}$ \\
\hline Time steps & $\begin{array}{l}\text { Initial time step: } 0.8 \mathrm{~s} \\
\text { Maximum time step: } 1 \text { day }\end{array}$ \\
\hline
\end{tabular}

\subsubsection{Phase 2: storm surge inundation}

Phase 2 simulates the occurrence of a storm surge overwash event. The surface domain was inundated with up to $1 \mathrm{~m}$ of water, based on observations following the 2004 storm surge on Andros Island. Flooding was simulated at a gradual rate of $0.1 \mathrm{~m}$ per $10 \mathrm{~min}$ stress period to satisfy model convergence criteria. Once full inundation was reached $(1.5 \mathrm{~h}$ after start of flooding), the maximum flood level was held constant for $2 \mathrm{~h}$. The actual period of inundation is not known, so this period was estimated to allow for sufficient salt water to enter the system. The salt concentration of the flood water was assigned as $35 \mathrm{~g} \mathrm{~L}^{-1}$ to represent seawater.

\subsubsection{Phase 3: recovery of the freshwater lens}

Phase 3 involved simulating the recovery of the freshwater lens. Several different scenarios were tested to enable comparison of recovery times when different factors are varied. All scenarios are based on the output from Phase 2, with the head and concentration boundaries of the surface domain unconstrained to allow release of the salty flood water. All other boundaries remained the same as the initial Phase 1 model.

A baseline recovery scenario was simulated for 10 years following the storm surge to allow the salt water to be flushed out of the system under the influence of recharge. In the baseline recovery model, the freshwater lens returns naturally to its original morphology.

Several other scenarios were simulated to represent different remedial actions. Following a storm surge event when the trenches are filled with salt water, a common remedial action is to drain out the trenches to remove the captured salt water (Illangasekare et al., 2006; Terry and Falkand, 2010; Chui and Terry, 2012). Draining, or pumping out the trenches, is meant to improve the recovery time and assist with removal of the salt water from the system. However, draining may often be delayed due to access constraints or due to lack of coordination and emergency response following the storm surge. Therefore, models were developed where the trenches are drained at different times and for different durations to evaluate the impact of draining protocol on recovery times of the freshwater lens and impact to water supply. Scenarios were modelled whereby draining was delayed by $1,2,3$, or 4 days after the storm surge (to reflect a delay in action). Other scenarios modelled draining initiated 1 day after the storm surge, whereby the duration of draining was 1,2 , or 3 days (to investigate the effect of sustained periods of draining).

For all recovery simulations, observation points were assigned within and immediately below the trench to monitor salt concentrations during recovery. This allowed for the comparison of recovery times between different scenarios, specifically the number of days for potable water to return to the trench and aquifer.

\section{Results}

\subsection{Long-acting stressors}

\subsubsection{Baseline model}

The simulated freshwater lens in the baseline model provides a snapshot of the average annual freshwater lens morphology. The model results indicate that a lens is present throughout most of the model domain (not shown); however, this study focuses on areas considered viable to provide a sustainable water supply, which are defined as having a lens thickness of greater than $2 \mathrm{~m}$ and a concentration of less than $0.4 \mathrm{~g} \mathrm{~L}^{-1}$ (Fig. 5). The shape of the lens is relatively symmetrical in cross-section with an average hydraulic head of $1.8 \mathrm{~m}$ a.s.l., which corresponds to typical elevations observed of $2 \mathrm{~m}$ a.s.l. The estimated total area of the viable freshwater lens on Andros Island is around $2000 \mathrm{~km}^{2}$ with a freshwater volume of $5.9 \times 10^{9} \mathrm{~m}^{3}$.

The baseline model was calibrated to observations, where available, although these were sparse and based on varying time periods (from the 1970s to early 2000s). The extent of the lens generally corresponds to observations of freshwater occurrence (i.e., the presence of wells and wellfields) and the results of previous studies (Little et al., 1973; Cant and Weech, 1986; Wolfe et al., 2001). The freshwater lens in the northern model is composed of a single lens that is much larger than the smaller, separate lenses in the southern model. Along the coastlines, particularly in the southern regions of the island, the simulated freshwater lens tends to be situated further inland than is observed; however, the depth 


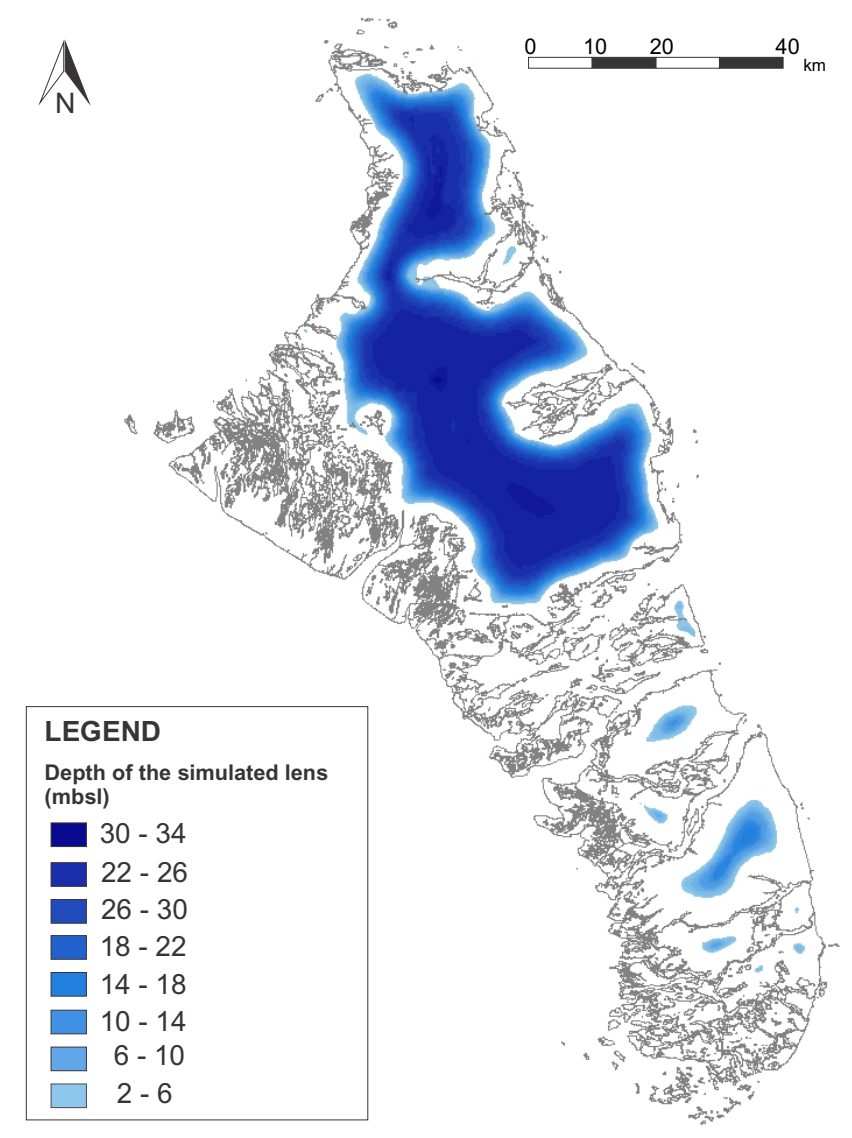

Figure 5. Baseline freshwater lens representing current conditions.

of the simulated lens in the south is consistent with field observations. The depth of the simulated lens in the northern regions of Andros Island falls within the range of maximum observed lens depth (up to $39 \mathrm{~m}$ b.g.s.), although it is slightly deeper than typical observations of around 15 to $20 \mathrm{~m}$ b.g.s. Because most of the model parameters are based on field data and sensitivity analyses, the deeper simulated lens is likely the result of slight over-estimation of recharge in the HELP model. HELP applies daily precipitation to the lithology profile evenly over a $24 \mathrm{~h}$ period, when in reality, precipitation events occur within shorter time intervals (hourly) and leads to some pooled water on the ground surface. Given that the intensity of the precipitation events is not accounted for in HELP, the resulting recharge estimates may be slightly overestimated. However, there is no clear basis upon which the recharge estimates can be adjusted to achieve better model calibration, due to the lack of field data for actual evapotranspiration and recharge.

Some local-scale variations are neglected in the model due to the limitations of the large grid cell size required to cover the area of the island, which resulted in a low resolution of the ground surface elevation. In addition, the model was developed to represent the average annual freshwater lens morphology and, therefore, does not include seasonal varia-
Table 5. Percent change in freshwater lens morphology relative to the baseline model for the combined effect of reduced recharge and sea level rise.

\begin{tabular}{lrr}
\hline $\begin{array}{l}\text { Modelled } \\
\text { region }\end{array}$ & $\begin{array}{r}\text { \% change } \\
\text { area }\end{array}$ & $\begin{array}{r}\% \text { change } \\
\text { volume }\end{array}$ \\
\hline Northern & -4.1 & -5.9 \\
Southern & -16.8 & -24.2 \\
\hline
\end{tabular}

tion. Although the worst case scenario (e.g., lowest recharge during the dry season) is not accounted for in this study, other studies have shown that there is little seasonal variation in groundwater levels for islands of similar hydrogeological settings (Momi et al., 2005). Overall, the simulated lens is within the range of observed depths, although it represents a slight over-estimation of the freshwater resources in the northern region of Andros Island. The model provides a generalized estimate of the freshwater lens morphology and serves as a reasonable baseline for investigating the impacts due to climate change stressors.

\subsubsection{Climate change models}

As noted above, the HELP model utilizes site-specific climate averages so that predictions can be made regarding the impact of future climate conditions on recharge. Recharge is projected to decrease by $11 \%$ in the northern model and decrease by $15 \%$ in the southern model by the 2090s relative to baseline (current) recharge. This is due largely to decreases in average annual precipitation, and slight increases in evapotranspiration rates. Minimal changes in soil storage were simulated in the HELP model.

The results of the climate change modelling, including a reduction in recharge and a rise in sea level, indicate that the freshwater lens will reduce in areal extent and volume under future climate change conditions. The percent change in freshwater lens area and volume relative to the baseline values are presented in Table 5. The change in area and volume of the lens indicate that the lens shrinks and thins in response to the stressors. For both the northern and southern models, simulations of reduced recharge alone result in the majority of freshwater lens reduction, with sea level rise contributing a smaller proportion of lens reduction. The freshwater lens in the southern model is predicted to incur a greater percentage of loss of lens compared to the northern model under climate change conditions. In the southern model, the results indicate a $19 \%$ volume loss due to reduced recharge compared to $5 \%$ volume loss due to sea level rise relative to baseline morphology. Whereas, in the northern model, $5 \%$ of volume loss is due to reduced recharge with $0.9 \%$ volume loss due to sea level rise. The simulated lens at the end of the 100 year simulation is presented, illustrating areal loss of lens relative to the baseline model (Fig. 6). 


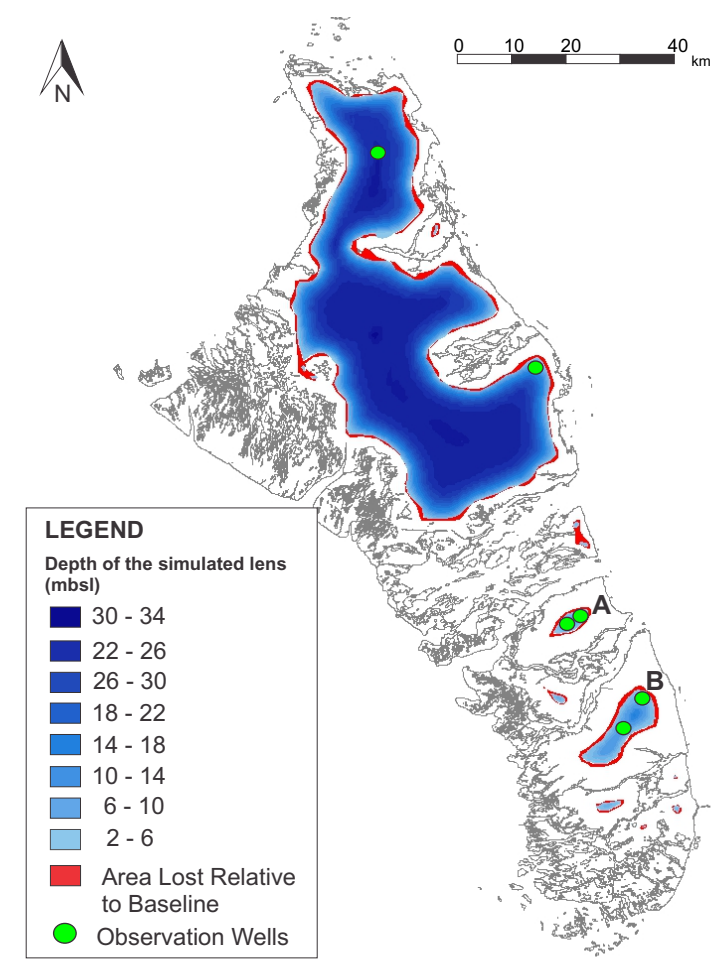

Figure 6. Model result for climate change simulations for the combined effect of reduced recharge and sea level rise, indicating area lost relative to baseline conditions.

The simulated time-varying dissolved salt concentrations in the observation wells are shown in Fig. 7. The simulated concentrations at most observation wells indicate that salinity in the lens progressively increases in response to the climate change shifts applied every 10 years starting at 50 years. Prior to 50 years, the model is spinning up from a fully salty state. Dissolved salt concentrations in all of the observation wells reach near steady state between stress periods (only very small changes continue to occur on the order of $\left.10^{-10} \mathrm{~g} \mathrm{~L}^{-1} \mathrm{day}^{-1}\right)$. The time to reach steady concentrations is relatively similar in all wells, ranging from 0.5 to 3 years and increasing as the simulation progresses. This indicates that even though the climate change shifts in each stress period are the same magnitude, the freshwater lens takes longer to adjust to the shifts as the cumulative magnitude of climate change increases.

The central wells were placed in areas that were anticipated to be more resilient to stressors, and the peripheral wells in areas that were anticipated to be more vulnerable to stressors (thereby showing a more immediate lens thinning). The simulation results are consistent with the anticipated behaviour. The peripheral observation wells have higher dissolved salt concentrations than the central wells because they are situated in the thinner part of the freshwater lens, and therefore, are more likely to intersect the base of the lens. The highest dissolved salt concentrations are in the periph-
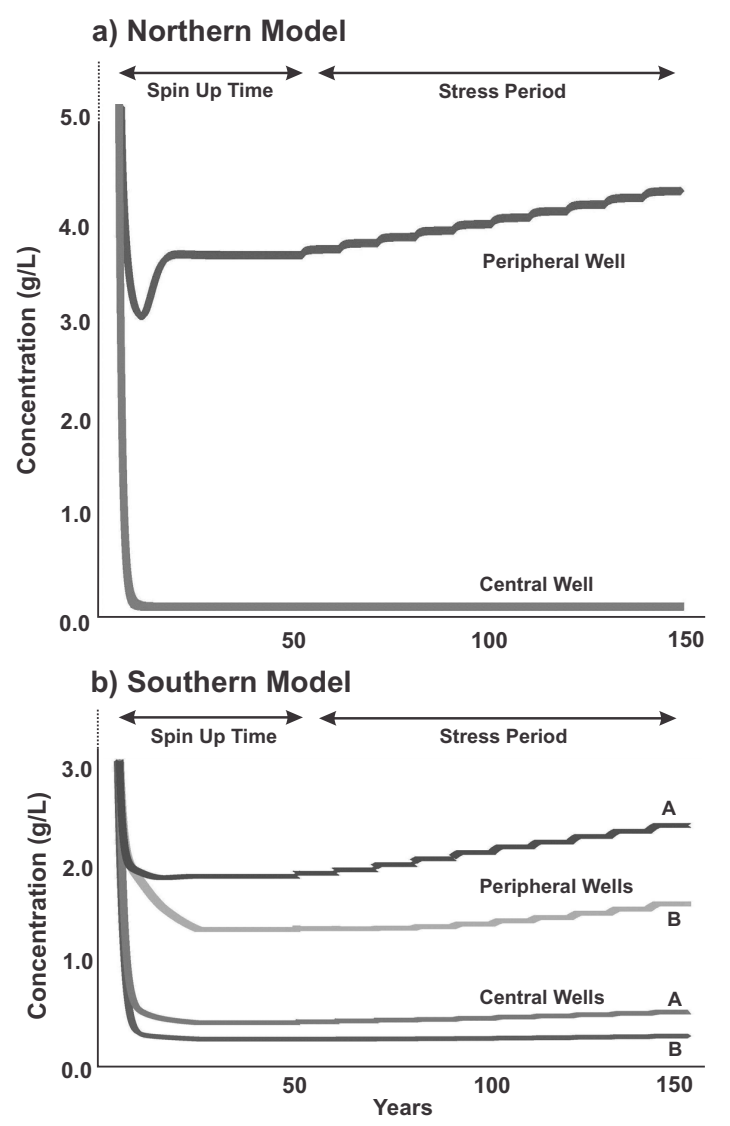

Figure 7. Simulated dissolved salt concentrations over time at the observation wells for climate change models. (a) Northern model, (b) southern model with two observation wells for each landmass shown.

eral well in the northern model, which is closer to the coast than the peripheral wells in the southern model. This is because the edge of the northern freshwater lens extends further coastward than the southern freshwater lens. Greater changes in dissolved salt concentration are also observed in the peripheral wells compared to the central wells, as would be expected.

\subsection{Short-acting stressor}

\subsubsection{Freshwater lens development and storm surge inundation}

The morphology of the freshwater lens reaches steady state within 25 years at a maximum depth of $23 \mathrm{~m}$ b.s.l. (metres below sea level) (Phase 1; Fig. 8a). The model is calibrated to observed conditions outlined in Table 3. The maximum elevation of the freshwater lens is observed in the trench at $1.8 \mathrm{~m}$ a.s.l. The vadose zone surrounding the trench is approximately $1.7 \mathrm{~m}$ thick. The gradient across the model domain is 0.0015 , with an average horizontal groundwater velocity of $0.87 \mathrm{~m} \mathrm{day}^{-1}$. The inflections on the sides of the 


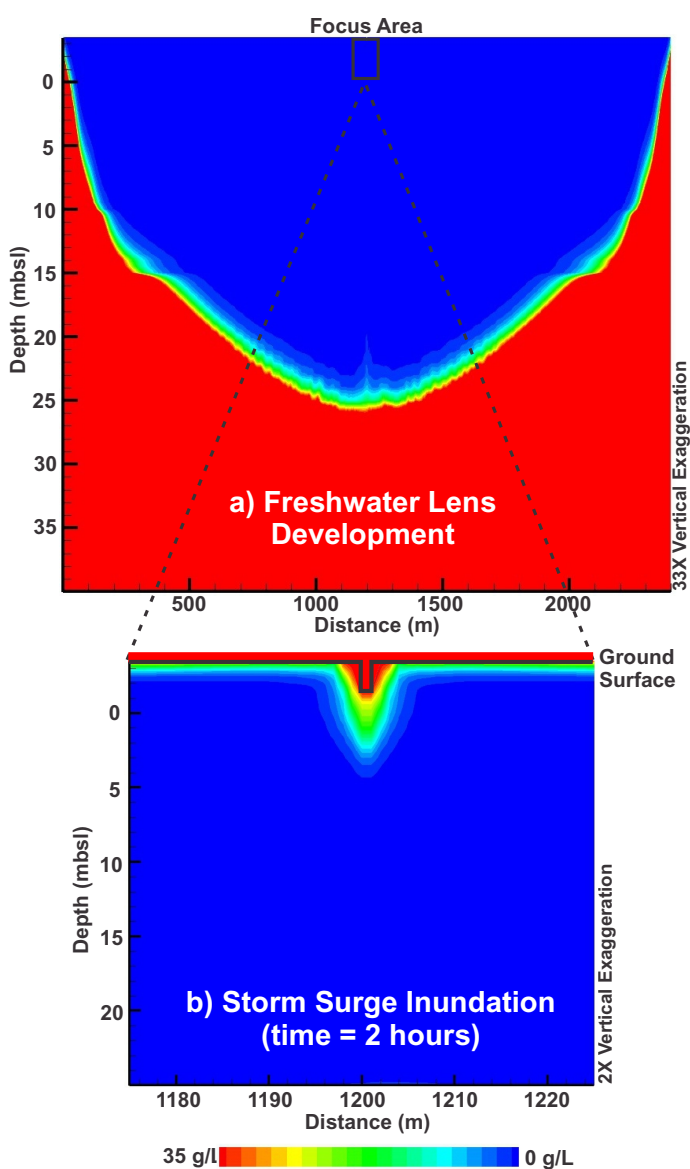

Figure 8. (a) Freshwater lens development after 50 years (Phase 1); (b) storm surge inundation in the focus area at $2 \mathrm{~h}$ (Phase 2).

lens at 9 and $14 \mathrm{~m}$ b.g.s. reflect the high hydraulic conductivity paleosol layers.

Simulation of storm surge inundation (Phase 2) resulted in high salt concentrations at the surface of the model up to $1 \mathrm{~m}$ above ground surface (Fig. 8b). The results of the inundation model are shown for a focus area within $25 \mathrm{~m}$ of the trench (focus area indicated in Fig. 8a). Within the $2 \mathrm{~h}$ inundation period, the salt water had already been transported into the vadose zone due to the hydraulic gradient associated with the surface flood, and had also filled the trench with salt water (Fig. 8b).

\subsubsection{Aquifer recovery}

The baseline recovery of the freshwater lens (natural recovery) is shown for six times post-storm surge (Fig. 9): $12 \mathrm{~h}$, 1 day, 2 days, 1 month, 2 years, and 10 years. The baseline recovery scenario indicates that the freshwater lens returns to its original morphology approximately 10 years post-storm surge. The salt water is transported from the surface domain into the aquifer system, where it forms a salt plume within the subsurface. This plume is flushed out over time due to
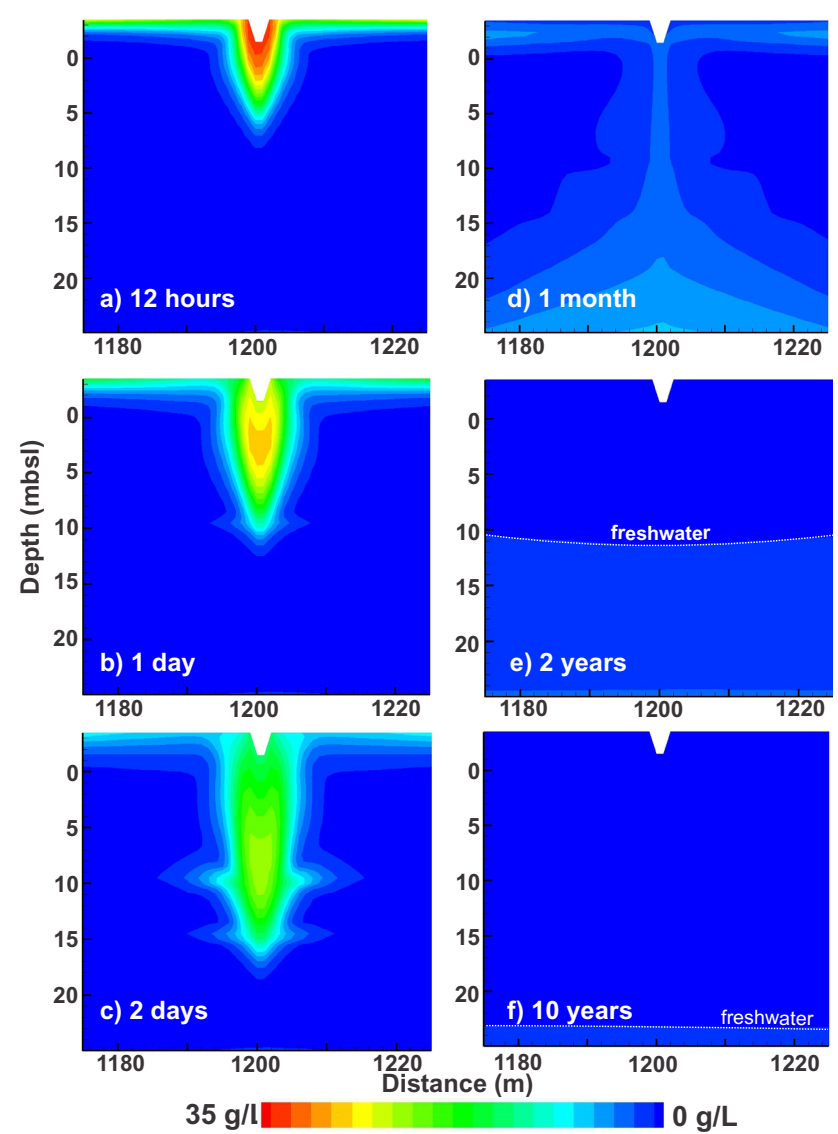

Figure 9. Baseline recovery of the freshwater lens post-storm surge at (a) $12 \mathrm{~h}$, (b) 1 day, (c) 2 days, (d) 1 month, (e) 2 years, and (f) 10 years.

the infiltrating freshwater recharge. Salt concentration within the trench returns to levels below the potable water threshold within 149 days following the storm surge for the baseline recovery scenario.

The results of the different draining scenarios are shown in Fig. 10, alongside the baseline recovery scenario, as relative concentration data over time, where 1.0 represents salt water and 0.0 represents freshwater. The number of days to reach potable concentration in the trenches is indicated for each scenario. Observed concentration data for the North Andros Wellfield trenches are also presented in Fig. 10. Trenches that were drained following the storm surge, and those that were isolated from the system and not drained, are distinguished by different symbols.

There is little difference in observed concentrations when comparing the trenches that were drained and those that were not. The observed concentrations are similar to the simulated concentrations immediately following the overwash event; however, at 1 year post-storm surge, the observed concentrations are slightly above the potable water threshold. By 2 years post-storm surge (not shown), the observed concentra- 


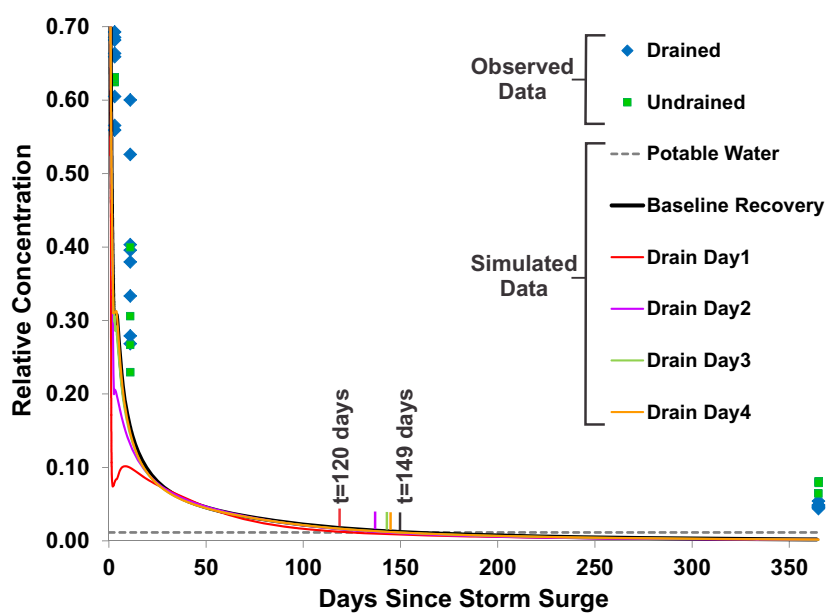

Figure 10. Observed and simulated concentrations within the trench. The times for concentrations to reach potable water threshold are indicated by the small vertical bars for the baseline recovery scenario (149 days) and the various scenarios of draining on different days following the surge (120 days for draining on day 1). The increase in concentration observed for Scenario Drain Day 1 represents the end of the draining period, when high concentration water re-enters the trench from the surrounding aquifer and vadose zone.

tions are similar to the simulated concentrations, and below the potable threshold.

Draining of the trenches generally results in a faster recovery. If draining occurs within 1 day of the storm surge, potable water returns to the trench by about 120 days (Fig. 10), approximately 1 month sooner compared to the baseline recovery simulation (149 days). With every day that draining is delayed, it takes longer for potable water to return to the trench (corresponding to the small vertical lines in Fig. 10 for each scenario). After a delay of 3 days, the recovery time for potable water to return is the same as the case when no remedial action is undertaken. Therefore, the improvements in recovery time are dependent on the timing of draining.

In contrast, the duration of draining (not shown) does not significantly improve recovery times. Draining that occurs for multiple days results in slightly longer times for potable water to return compared to short-duration draining (i.e., over a single day).

As mentioned earlier, the observed data at 1 year poststorm surge are higher than the model results, indicating that the trenches on Andros Island recovered slower than the model results. This is likely the result of several factors:

1. The amount of salt water entering the aquifer system largely depends on the time of inundation. As this was unknown, it was assumed to be a $2 \mathrm{~h}$ inundation. However, the inundation may have lasted much longer, as no observations of the area were made until 3 days after the storm surge. To account for this uncertainty, a Phase 2 model was run with a longer inundation period of 2 days. The recovery from this storm surge scenario took at least 2 months longer, with higher concentrations at 1 year post-storm surge. However, the freshwater lens morphology recovered at the same time as the baseline scenario.

2. The amount of recharge that specifically occurred on Andros Island may have been different during 20042005. Alternate recovery simulations were run where recharge was applied as monthly averages based on the 2004 and 2005 rainfall data for Andros Island. These simulations resulted in longer recovery times, up to 6 weeks more than baseline recovery.

3. As previously discussed, the HELP recharge results may over-estimate actual recharge to the freshwater lens. Therefore, additional models were run with recharge applied at half the baseline amount. These simulations indicated that recovery was delayed by 2 months.

4. Additional factors may impact the calibration to observed data. The models were developed based on field studies that were not all specific to the North Andros Wellfield area; therefore, hydrogeological conditions (such as porosity or hydraulic conductivity) at the wellfield may differ from those on the island scale.

5. The exact timing, duration and method of draining utilised on Andros Island are also unclear. While the best possible information was obtained from the Bahamas Water and Sewerage Corporation, it is likely that the details of operations were inexact.

6. Lastly, other hurricanes passed near to Andros Island in the weeks and months following Hurricane Frances; however, it is unknown whether any of these caused an additional storm surge event (NOAA - National Hurricane Center, National Oceanic and Atmospheric Administration, 2014). Regardless, the close passage of other storms would have attributed to atypical rainfall events. In addition, the concentration of recharging freshwater may be higher than $0 \mathrm{gL}^{-1}$ during storms due to salt spray, thereby introducing higher salt concentrations at the surface and delaying recovery.

Although many factors contribute to the uncertainty in the calibration, the recovery models are likely reasonable representations that allow for comparison of the impact of remedial actions on recovery.

\section{Discussion}

\section{$5.1 \quad$ Long-acting stressors}

The volume and area of the freshwater lens are reduced under stressed conditions, indicating that the lens both shrinks and 
thins. A significant impact is observed in areas where the lens shrinks (i.e., along the periphery), as most settlements and the related infrastructure are typically near the coast on small islands (Ranjan et al., 2009; Cashman et al., 2010). As a result, any changes in the freshwater lens morphology within the coastal zone may affect access and availability of freshwater near the population centres.

The loss of freshwater lens area and extent under climate change conditions is attributed more to the impact of changes to groundwater recharge than the impact of sea level rise. Although loss of land surface due to sea level rise was not simulated in the models, estimates based on ground surface elevation suggest loss of land surface (and resulting loss of freshwater lens volume) is limited. On islands with lower topography and/or smaller land area, inundation would have a greater effect on loss of freshwater lens volume. The model results for Andros Island are supported by other studies, which show that conditions of reduced groundwater recharge (or prolonged drought, which results in reduced recharge) disturb the balance of freshwater outflow necessary to maintain the extent and thickness of the freshwater lens, thereby leading to loss of freshwater resources due to saltwater intrusion (Ranjan et al., 2009; White and Falkland, 2010; Mollema and Antonellini, 2013). In addition, the hydrogeological system on Andros Island is recharge-limited, meaning that the freshwater lens is able to rise in the subsurface in response to sea level rise. Therefore, it is less vulnerable to sea level rise because the freshwater lens is able to maintain a balance between the hydraulic gradient of the fresh and salt water (Michael et al., 2013). This assumption is only valid to a point; for higher magnitudes of sea level rise, the freshwater lens would likely become topographically limited and, therefore, have a larger response (i.e., loss of lens) due to sea level rise. Although sea level rise appears not to be a significant factor for saltwater intrusion on Andros Island, it may increase the island's vulnerability to other events, such as extreme high tides and storm surge overwash. These events have the potential to result in significant impacts to the freshwater lens, as is discussed below.

The northern regions of Andros Island appear to be more resilient to climate change stressors than the southern regions. Several factors contribute to the difference in response between the northern and southern regions: (1) the south is composed of smaller landmasses, resulting in smaller areas for the freshwater lenses to develop; (2) significantly less rainfall occurs in the south, meaning that there is less recharge to sustain the freshwater lenses; and (3) lower recharge results in a thinner lens developing, leading to lower hydraulic gradient of the freshwater lens. The combined impact of these factors is that the southern region of Andros Island has smaller freshwater lenses that are more vulnerable to damage from stressors.

The simulated freshwater lens on Andros takes longer to respond to climate change stressors as the magnitude of the cumulative stress increases (i.e., lower recharge and higher sea level). The implication is that as climate change progresses over time, the ability of the freshwater lens to respond to these changes decreases. Because recharge is the main driver of lens formation and maintenance, when the rate of recharge is reduced, the response time of the hydrogeological system is also reduced. This has been observed in laboratory experiments (Stoeckl and Houben, 2012) whereby the lens takes longer to reach steady state when there is reduced input (i.e., specified flux or concentration boundaries) to the system. Therefore, areas where there is less recharge, such as the southern regions of Andros Island, are expected to take longer to react and adapt to stresses to the hydrogeological system.

\subsection{Short-acting stressor}

Trench-based wellfields result in large salt plumes that develop in the aquifer following a storm surge overwash. This is because the trench provides direct access for inundating salt water to travel into the aquifer. The salt plume remains larger surrounding the trench than in the rest of the aquifer throughout recovery, and takes 3 months longer to recover than the surrounding aquifer. This is supported by other studies, where it was observed and modelled that areas where salt water pools or is collected during inundation (such as open boreholes or depressions) result in longer recovery times (Terry and Falkland, 2010; Chui and Terry, 2012).

The timing of remedial action (specifically draining of the trenches) is more critical than the duration of draining. It is critical to drain the trenches as soon as possible following a storm surge overwash in order to remove the initial salt load to the aquifer before it is transported deeper into the aquifer. After a certain period of delay, there is no improvement in recovery achieved by draining. This is illustrated in the simulation results as well as the observation data, where there is little improvement in recovery for trenches on Andros Island that were drained after a 4 day delay. The time of this delay threshold, where there is still benefit to be gained in draining the trenches, will depend on many factors, such as the hydraulic conductivity, the groundwater velocity, and recharge rates. For most typical low-lying islands, the delay threshold is likely quite soon after storm surge due to the high hydraulic conductivity of geological materials normally found on low-lying islands (Ayers and Vacher, 1986). Coarser aquifer material may allow for faster salt transport into the aquifer (Chui and Terry, 2012). Although this effect may also speed up recovery, it means that there is a limited time in which to perform remedial action to remove the salt water. On Andros Island, the delay threshold is 3 days. The duration of draining should also be short, because longer durations of draining may result in slower recovery times. This is likely due to the fact that draining of the trenches removes the recharging freshwater, along with the salt water. 


\section{Conclusions}

Stressors act over varying spatial and temporal scales to impact the freshwater lenses of low-lying islands. Both short and long-acting stressors may result in significant loss of freshwater resources. The model results are inherently uncertain due to uncertainty associated with the input data, model conceptualization, and stressor scenarios. The greatest uncertainty lies in the simplification of the hydrogeology and the associated parameters. This is largely due to limited studies having been conducted on Andros. However, small islands often have limited capacity for hydrogeological investigations. Therefore, this study was not predictive, but rather aimed to identify the likely response based on the hydrogeological setting and the mean projected climate state derived from multiple climate change model scenarios. To address uncertainty rigorously, a series of models with a range of input parameters and climate scenarios would be required; however, this was beyond the scope of the current study. Within these limitations, the results of the study provide the following conclusions:

1. The impacts of stressors on the freshwater lens are predicted to occur primarily in areas where the freshwater lens is smaller or thinner, such as the periphery of the lens. As most settlements are concentrated within the coastal zone, even small-scale changes to the freshwater lens morphology in these areas may have significant implications for freshwater sustainability.

2. Change to groundwater recharge is identified as a key stressor to Andros Island, where greater impacts on the freshwater lens are observed in areas with lower recharge.

3. The response time of the freshwater lens (time to reach steady state) increases as the magnitude of the stressors increase. With increasing magnitude of change to the hydrogeological system, the freshwater lens takes longer to adjust to the new state.

4. The freshwater lens is generally able to recover from storm surge inundation over time as fresh recharge flushes the salt plume out of the aquifer. Eventually, the freshwater lens returns to the original morphology.

5. Trench-based wellfields may increase the potential storm surge impacts on the freshwater lens, depending on the hydraulic conductivity, the vadose zone thickness, and land cover. However, they also allow for remedial action (such as draining of the trenches) to be undertaken, which can improve recovery times. The sooner draining occurs, the more improvement in recovery, because, if draining is delayed by too long (in this case, 3 days or more), there is no improvement in recovery. The duration of draining has less effect on recovery and only needs to occur for a short period of time.
Acknowledgements. Funding for this research was provided by the Natural Sciences and Engineering Research Council (NSERC) through a Discovery Grant to Diana Allen, and a grant to Simon Fraser University by The Nature Conservancy through the Royal Bank of Canada's Blue Water Project ${ }^{\mathrm{TM}}$. The authors also acknowledge the contribution of the Bahamas Water and Sewerage Corporation in providing data for model calibration.

Edited by: M. Bakker

\section{References}

Allen, D. M., Cannon, A. J., Toews, M. W., and Scibek, J.: Variability in simulated recharge using different GCMs, Water Resour. Res., 46, W00F03, doi:10.1029/2009WR008932, 2010.

Anderson Jr., W. P.: Aquifer salinization from storm overwash, J. Coast. Res., 18, 413-420, 2002.

Ataie-Ashtiani, B., Werner, A. D., Simmons, C. T., Morgan, L. K., and $\mathrm{Lu}, \mathrm{C} .:$ How important is the impact of land-surface inundation on seawater intrusion caused by sea-level rise?, Hydrogeol. J., 21, 1673-1677, doi:10.1016/j.advwatres.2012.03.004, 2013.

Ayers, J. F. and Vacher, H. L.: Hydrogeology of an atoll island: A conceptual model from detailed study of a Micronesian example, Ground Water, 24, 185-198, doi:10.1111/j.17456584.1986.tb00994.x, 1986.

Barlow, P. M.: Ground Water in Freshwater-Saltwater Environments of the Atlantic Coast, US Department of the Interior, US Geol. Surv. Circular 1262, Reston, Virginia, USA, 2003.

Beach, D. K. and Ginsburg, R. N.: Facies succession of PliocenePleistocene carbonates, northwestern Great Bahama Bank, AAPG Bull.-Am. Assoc. Petr. Geol., 64, 1634-1642, 1980.

Bear, J., Cheng, A. H. D., Sorek, S., Herrera, I., and Ouazar, D. (Eds.): Seawater Intrusion in Coastal Aquifers, Kluwer Academic Publishers, Dordrecht, the Netherlands, 1999.

Biasutti, M., Sobel, A. H., Camargo, S. J., and Creyts, T. T.: Projected changes in the physical climate of the gulf coast and caribbean, Climatic Change, 112, 819-845, doi:10.1007/s10584011-0254-y, 2012.

Boardman, M. R. and Carney, C.: Influence of sea level on the origin and diagenesis of the shallow aquifer of Andros Island, Bahamas, in: Proceedings of the Eighth Symposium on the Geology of the Bahamas, Bahamian Field Station, edited by: Carew, J. L., San Salvador, Bahamas, 13-32, 1997.

Bobba, A. G.: Numerical modeling of salt-water intrusion due to human activities and sea-level change in the Godavari Delta, India, Hydrolog. Sci. J., 47, 67-80, 2002.

Bowleg, J. and Allen, D. M.: Effects of storm surges on groundwater resources, North Andros Island, Bahamas, in: Climate Change Effects on Groundwater Resources: A Global Synthesis of Findings and Recommendations, IAH International Contributions to Hydrogeology, editd by: Treidgel, H., Martin-Bordes, J. L., and Gurdak, J. J., CRC Press, London, UK, 2011.

Bukowski, J. M., Carney, C., Ritzi Jr., R. W., and Boardman, M. R.: Modeling the fresh-salt water interface in the Pleistocene aquifer on Andros Island, Bahamas, in: Proceedings of the Ninth Symposium on the Geology of the Bahamas, Bahamian Field Station, edited by: Curran, H. A. and Mylroie, J. E., San Salvador, Bahamas, 1-13, 1999. 
Cant, R. V. and Weech, P. S.: A review of the factors affecting the development of Ghyben-Herzberg lenses in the Bahamas, J. Hydrol., 84, 333-343, doi:10.1016/0022-1694(86)90131-9, 1986.

Cashman, A., Nurse, L., and Charlery, J.: Climate change in the Caribbean: the water management implications, J. Environ. Develop., 19, 42-67, doi:10.1177/1070496509347088, 2010.

Chui, T. F. M. and Terry, J. P.: Modeling fresh water lens damage and recovery on atolls after storm-wave washover, Ground Water, 50, 412-420, 2012.

Chui, T. F. M. and Terry, J. P.: Influence of sea-level rise on freshwater lenses of different atoll island sizes and lens resilience to storm-induced salinization, J. Hydrol., 502, 18-26, 2013.

Falkland, A. (Ed.): Hydrology and water resources of small island: a practical guide, United Nations Educational, Scientific, and Cultural Organization - UNESCO, Paris, 1991.

Franklin, J., Pasch, R., Avila, L., Beven, J., Lawrence, M., Stewart, S., and Blake, E.: Atlantic hurricane season of 2004, Mon. Weather Rev., 134, 981-1025, 2006.

Freeze, R. A. and Cherry, J. A.: Groundwater, Prentice-Hall, Upper Saddle River, NJ, USA, 1977.

Goderniaux, P., Brouyere, S., Fowler, H. J., Blenkinsop, S., Therrien, R., Orban, P., and Dassargues, A.: Large scale surfacesubsurface hydrological model to assess climate change impacts on groundwater reserves, J. Hydrol., 373, 122-138, 2009.

Green, T. R., Taniguchi, M., Kooi, H., Gurdak, J. J., Allen, D. M., Hiscock, K. M., and Aureli, A.: Beneath the surface of global change: Impacts of climate change on groundwater, J. Hydrol., 405, 532-560, doi:10.1016/j.jhydrol.2011.05.002, 2011.

Illangasekare, T., Tyler, S. W., Clement, T. P., Villholth, K. G., Perera, A. P. G. R. L., Obeysekera, J., Gunatilaka, A., Panabokke, C. R., Hyndman, D. W., Cunningham, K. J., Kaluarachchi, J. J., Yeh, W. W. G., van Genuchten, M. T., and Jensen, K.: Impacts of the 2004 tsunami on groundwater resources in Sri Lanka, Water Resour. Res., 42, W05201, doi:10.1029/2006WR004876, 2006.

IPCC: Climate Change 2007: The Physical Science Basis, in: Contribution of Working Group I to the Fourth Assessment Report of the Intergovernmental Panel on Climate Change, edited by: Solomon, S., Qun, D., Manning, M., Chen, Z., Marquis, M., Averyt, K. B., Tignor, M., and Miller, H. L., Cambridge University Press, Cambridge, UK, 2007.

IPCC: Climate Change 2014: Impacts, Adaptation, and Vulnerability, Part B: Regional Aspects, in: Contribution of Working Group II to the Fifth Assessment Report of the Intergovernmental Panel on Climate Change, edited by: Barros, V. R., Field, C. B., Dokken, D. J., Mastrandrea, M. D., Mach, K. J., Bilir, T. E., Chatterjee, M., Ebi, K. L., Estrada, Y. O., Genova, R. C., Girma, B., Kissel, E. S., Levy, A. N., MacCracken, S., Mastrandrea, P. R., and White, L. L., Cambridge University Press, Cambridge, UK and New York, NY, USA, 2014.

Jyrkama, M. I. and Sykes, J. F.: The impact of climate change on spatially varying groundwater recharge in the grand river watershed (Ontario), J. Hydrol., 338, 237-250, doi:10.1016/j.jhydrol.2007.02.036, 2007.

Langevin, C. D. and Zygnerski, M.: Effect of sea-level rise on salt water intrusion near coastal well field in southeastern Florida, Ground Water, 51, 781-803, 2013.

Langevin, C. D., Thorne, D. T., Dausman, A. M., Sukop, M. C., and Guo, W.: SEAWAT Version 4: A Computer Program for Simulation of Multi-Species Solute and Heat Transport,
US Geol. Surv. Techniques and Methods Book 6, Chapter A22, US Geological Survey, Florida, USA, 2007.

Little, B. G., Buckley, D. K., Jefferiss, A., Stark, J., and Young, R. N.: Land resources of the commonwealth of the Bahamas, Volume 4 Andros Island, Land Resources Division, Tolworth Tower, Surrey, England, 1973.

McSweeney, C., New, M., Lizcano, G., and Lu, X.: The UNDP Climate Change Country Profiles, B. Am. Meteorol. Soc., 91, 157166, doi:10.1175/2009BAMS2826.1, 2010.

Michael, H. A., Russoniello, C. J., and Byron, L. A.: Global assessment of vulnerability to sea-level rise in topography-limited and recharge-limited coastal groundwater systems, Water Resour. Res., 49, 2228-2240, doi:10.1002/wrcr.20213, 2013.

Mollema, P. N. and Antonellini, M.: Seasonal variation in natural recharge of coastal aquifers, Hydrogeol. J., 21, 787-797, doi:10.1007/s10040-013-0960-9, 2013.

Momi, K., Shoji, J., and Nakagawa, K.: Observations and modeling of seawater intrusion for a small limestone island aquifer, Hydrol. Process., 19, 3897-3909, doi:10.1002/hyp.5988, 2005.

NOAA: http://www.nhc.noaa.gov/, last access: 10 June 2014.

Obeysekera, J., Park, J., Irizarry-Ortiz, M., Barnes, J., and Trimble, P.: Probabilistic projection of mean sea level and coastal extremes, J. Waterw. Ports Coast. Ocean Eng., 139, 135-141, doi:10.1061/(ASCE)WW.1943-5460.0000154, 2013.

Oude Essink, G. H. P.: Improving fresh groundwater supply problems and solutions, Ocean Coast. Manage., 44, 429-449, doi:10.1016/S0964-5691(01)00057-6, 2001.

Rahmstorf, S.: A semi-empirical approach to projecting future sealevel rise, Science, 315, 368-370, doi:10.1126/science.1135456, 2007.

Ranjan, P., Kazama, S., Sawamoto, M., and Sana, A.: Global scale evaluation of coastal fresh groundwater resources, Ocean Coast. Manage., 52, 197-206, doi:10.1016/j.ocecoaman.2008.09.006, 2009.

Rasmussen, P., Sonnenborg, T. O., Goncear, G., and Hinsby, K.: Assessing impacts of climate change, sea level rise, and drainage canals on saltwater intrusion to coastal aquifer, Hydrol. Earth Syst. Sci., 17, 421-443, doi:10.5194/hess-17-421-2013, 2013.

Ritzi, R., Bukowski, J., Carney, C., and Boardman, M.: Explaining the thinness of the fresh water lens in the Pleistocene carbonate aquifer on Andros Island, Bahamas, Ground Water, 39, 713-720, doi:10.1111/j.1745-6584.2001.tb02361.x, 2001.

Robins, N. and Lawrence, A.: Some hydrogeological problems peculiar to various types of small islands, Water Environ. J., 14, 341-346, 2000.

Schneider, J. and Kruse, S.: A comparison of controls on freshwater lens morphology of small carbonate and siliciclastic islands: Examples from barrier islands in Florida, USA, J. Hydrol., 284, 253-269, doi:10.1016/j.jhydrol.2003.08.002, 2003.

Schroeder, P. R., Dozier, T. S., Zappi, P. A., McEnroe, B. M., Sjostrom, J. W., and Peyton, R. L.: The Hydrologic Evaluation of Landfill Performance (HELP) model: Engineering documentation for Version 3, Rep. EPA/600/R-94/168b, US Environmental Protection Agency, Washington, D.C., USA, 1994.

Scibek, J. and Allen, D. M.: Modeled impacts of predicted climate change on recharge and groundwater levels, Water Resour. Res., 42, W11405, doi:10.1029/2005WR004742, 2006. 
Stoeckl, L. and Houben, G.: Flow dynamics and age stratification of freshwater lenses: Experiments and modeling, J. Hydrol., 458, 9-15, doi:10.1016/j.jyhrol.2012.05.070, 2012.

Sulzbacher, H., Wiederhold, H., Siemon, B., Grinat, M., Igel, J., Burschil, T., Günther, T., and Hinsby, K.: Numerical modelling of climate change impacts on freshwater lenses on the North Sea Island of Borkum using hydrological and geophysical methods, Hydrol. Earth Syst. Sci., 16, 3621-3643, doi:10.5194/hess-163621-2012, 2012.

Tarbox, K. L.: Occurrence and development of water resources in The Bahamas, in: Proceedings of the Third Symposium on the Geology of the Bahamas, Bahamian Field Station, edited by: Curran, H. A., San Salvador, Bahamas, 139-144, 1987.

Terry, J. P. and Chui, T. F. M.: Evaluating the fate of freshwater lenses on atoll islands after eustatic sea-level rise and cyclonedriven inundation: A modeling approach, Global Planet. Change, 88-89, 76-84, doi:10.1016/j.gloplacha.2012.03.008, 2012.

Terry, J. P. and Falkland, A. C.: Responses of atoll freshwater lenses to storm-surge overwash in the Northern Cook Islands, Hydrogeol. J., 18, 749-759, 2010.

Therrien, R., McLaren, R., Sudicky, E. and Panday, S.: HydroGeoSphere - A three-dimensional numerical model describing fully-integrated subsurface and surface flow and solute transport, University of Waterloo and Université Laval, Waterloo, Canada, 2010.

Toews, M. W. and Allen, D. M.: Evaluating different GCMs for predicting spatial recharge in an irrigated arid region, J. Hydrol., 374, 265-281, doi:10.1016/j.jhydrol.2009.06.022, 2009

UNDP - United Nations Development Programme: Climate Change Country Profiles, The Bahamas, 2010.

Vacher, H. L.: Dupuit-Ghyben-Herzberg analysis of strip-island lenses, Bull. Geol. Soc. Am., 100, 580-591, doi:10.1130/00167606(1988)100<0580:DGHAOS>2.3.CO;2, 1988.

Vacher, H. L. and Quinn, T. M. (Eds.): Geology and hydrogeology of carbonate island, in: Developments in Sedimentology Vol. 54, Elsevier, Tampa Bay, Florida, USA, 1997.
Wallis, T. N., Vacher, H. L., and Stewart, M. T.: Hydrogeology of freshwater lens beneath a Holocene strandplain, Great Exuma, Bahamas, J. Hydrol., 125, 93-109, doi:10.1016/00221694(91)90085-V, 1991.

Werner, A. D. and Simmons, C. T.: Impact of sea-level rise on sea water intrusion in coastal aquifers, Ground Water, 47, 197-204, doi:10.1111/j.1745-6584.2008.00535.x, 2009.

Werner, A. D., Jakovovic, D., and Simmons, C. T.: Experimental observations of saltwater up-coning, J. Hydrol., 373, 230-241, doi:10.1016/j.jhydrol.2009.05.004, 2009.

Whitaker, F. and Smart, P.: Climatic control of hydraulic conductivity of Bahamian limestones, Ground Water, 35, 859-868, doi:10.1111/j.1745-6584.1997.tb00154.x, 1997.

White, I. and Falkland, A.: Management of freshwater lenses on small Pacific islands, Hydrogeol. J., 18, 227-246, doi:10.1007/s10040-009-0525-0, 2010.

White, N. J., Church, J. A., and Gregory, J. M.: Coastal and global averaged sea level rise for 1950 to 2000, Geophy. Res. Lett., 32, L01601, doi:10.1029/2004GL021391, 2005.

WHO - World Health Organisation: Guidelines for drinking-water quality, 4th Edn., Geneva, Switzerland, 2011.

Wolfe, P. J., Adams, A. L., and Carney, C. K.: A resistivity study of the freshwater lens profile across North Andros Island, The Bahamas, in: Proceedings of the Tenth Symposium on the Geology of the Bahamas and Other Carbonate Regions, edited by: Greenstein, B. J. and Carney, C. K., Gerace Research Center, San Salvador, Bahamas, 31-40, 2001.

Yang, J., Graf, T., Herold, M., and Ptak, T.: Modeling the effects of tides and storm surges on coastal aquifers using a coupled surface-subsurface approach, J. Contam. Hydrol., 149, 61-75, 2013.

Younger, P. L.: Simple generalized methods for estimating aquifer storage parameters, Q. J. Eng. Geol. Hydrogeol., 26, 127-135, doi:10.1144/GSL.QJEG.1993.026.02.04, 1993. 